\title{
HUBUNGAN PEGUASAAN KALIMAT EFEKTIF DENGAN KEMAMPUAN MENULIS TEKS EKSPOSISI OLEH SISWA KELAS X SMA NEGERI 3 MEDAN \\ TAHUN AJARAN 2016/107
}

\author{
Oleh \\ Khaida Munawarah \\ Prof. Dr. Tiur Asi Siburian, M.Pd
}

\begin{abstract}
ABSTRAK
Penelitian ini bertujuan untuk mengetahui hubungan penguasaan kalimat efektif dengan kemampuan menulis eksposisi siswa kelas X SMA Negeri 3 Medan. Penelitian ini dilaksanakan pada semester ganjil tahun ajaran 2016/2017. Lokasi Penelitian, penelitian di SMA Negeri 3 Medan Jalan Budi kemasyarakatan 3, Medan, Sumtera Utara. Populasi penelitian adalah seluruh siswa kelas X IPA SMA Negeri 3 Medan yang terdiri dari 19 lokal sebanyak 854 orang siswa. Penarikan sampel dilakukan dengan menggunakan teknik proportional random sampling. Sampel diambil 10\% dari jumlah populasi yaitu sebesar 85 orang siswa. Teknik analisis data dilakukan secara derskripstif kuantitatif korelasional. Kemampuan menulis teks eksposisi didominasi oleh siswa yang memiliki nilai dalam kategori sangat baik, yakni 11 orang siswa $(12,94 \%)$, siswa yang memiliki nilai dalam kategori baik sebanyak 70 orang siswa $(82,35 \%)$ dan siswa yang memiliki nilai dalam kategori cukup baik sebanyak 4 orang siswa (4.70\%). Tidak ada satupun siswa yang memiliki nilai dalam kategori kurang baik dan sangat kurang baik. Hubungan penguasaan kalimat efektif dengan kemampuan menulis teks eksposisi oleh siswa pada sampel 85 orang kelinieran persamaan regresi $Y=62,32+0,601 \mathrm{X}$ berarti pada taraf signifikan $\alpha=0,05$. Untuk uji keberartian regresi di peroleh nilai hitung $\mathrm{F}_{\text {hit }}=2,111$ sedangkan nilai $\mathrm{F}_{\text {tabel }}=1,450$ dengan $\mathrm{dk}=\mathrm{N}-1=84$. Karena nilai $F_{\text {hitung }}>F_{\text {tabel }}(2,111>1,450)$ maka dapat disimpulkan bahwa kelinieran persamaan regresi $Y=62,32+0,601 \mathrm{X}$ berarti pada taraf signifikan $\alpha=$ 0,05 dengan korelasi yang tergolong rendah. Keterkaitan penguasaan kalimat efektif dengan kemampuan menulis teks eksposisi ke dalam sebuah paragraf sebuah tulisan sangatlah ditentukan bagimana siswa tersebut menggunakan kata yang tepat sehingga tujuan atau makna yang terkandung dalam kalimat dapat disampaikan dengan baik.
\end{abstract}

Kata Kunci: Penguasaan Kalimat Efektif, Kemampuan Menulis Teks Eksposisi

\section{PENDAHULUAN}

Bahasa sebagai alat komunikasi mempunyai peranan penting dalam kehidupan manusia. Melalui bahasa, komunikasi antara penutur dan pendengarnya dapat berlangsung dengan baik sehingga informasi yang disampaikan penutur dapat ditanggapi atau diberi reaksi 
oleh penerima tuturan. Bahasa bukan hanya sekedar berfungsi sebagai alat berkomunikasi, tetapi untuk mengungkapkan ide, pikiran, dan perasaan yang diwujudkan dalam bentuk kata atau rangkaian kata.

Penggunaan bahasa sebagai alat komunikasi direalisasikan dalam empat keterampilan berbahasa, yaitu membaca, menyimak, menulis, dan berbicara.Tarigan (2008:21) menyatakan "Menulis merupakan kegiatan menuangkan atau melukiskan lambang-lambang grafik yang menggambarkan suatu bahasa yang dipahami seseorang, agar orang lain dapat membaca lambang-lambang grafik tersebut."

Keterampilan menulis membutuhkan ketekunan dan kreativitas.Siswa dituntut menemukan ide dan merangkai kata untuk menghasilkan tulisan yang baik.Dilihat dari fungsinya, kegiatan menulis juga memiliki beberapa manfaat seperti yang diungkapkan oleh Akhadiah, Maidar, dan Sakura (1999: 1-3), yaitu "Dapat menambah wawasan mengenai suatu topik karena penulis mencari sumber informasi tentang topik tersebut, sarana mengembangkan daya pikir atau nalar dengan mengumpulkan fakta, menghubungkannya, kemudian menarik kesimpulan".Hal ini dikarenakan keterampilan menulis bertujuan untuk melatih siswa dalam mengembangkan ide dan menyusunnya menjadi tulisan yang lebih rinci agar mudah dipahami oleh pembaca. Begitu pula dalam menyusun teks eksposisi, pada dasarnya teks eksposisi merupakan teks yang disusun untuk memberikan pengetahuan maupun informasi kepada orang lain agar bertambah pengetahuannya.

Penggunaan kalimat efektif banyak ditemukan dalam teks eksposisi.Teks eksposisi adalah teks yang bertujuan menyampaikan pendapat terhadap suatu hal, bersifat objek, di perjelas dengan fakta dan di akhiri dengan penegasan.Oleh karena itu penggunaan kalimat efektif bisa dijadikan bahan belajar menggunakan bahasa yang baik dan benar sesuai dengan kaidah kebahasaan.

Penguasaan kalimat efektif dalam menulis teks eksposisi sangat membatu pembaca satu pemikiran dengan penulisnya. Kalimat efektif adalah kalimat yang dapat mengomunikasikan pikiran atau perasaan pembicara atau penulis kepada pendengar atau pembaca secara tepat dan jelas sehingga tidak terjadi keraguan dan kesalahan pengertian.

Keterkaitan penguasaan kalimat efektif dengan aktifitas menulis teks eksposisi ke dalam bentuk paragraf sangatlah ditentukan bagaimana siswa tersebut menggunakan kata yang tepat sehingga tujuan atau makna yang terkandung dalam kalimat dapat tersampaikan dengan baik, memiliki perbendaharaan kata yang luas dan memilih kata yang tepat ketika hendak menulis, karena dengan adanya penguasaan kalimat efektif tersebut, siswa akan lebih 
mudah dalam menulis. Jika penguasaan kalimat efektiif masih rendah, siswa akan kurang mampu menulis teks eksposisi

Kurikulum 2013, keterampilan menulis merupakan salah satu pelajaran dalam Bahasa Indonesia yang harus diajarkan. Kompetensi Dasar pembelajaran Bahasa Indonesia yang mengacu pada Kurikulum 2013 kelas X adalah memahami teks hasil observasi, teks ekposisi, anekdot, hikayat, ikhtisar buku, teks negoisasi, debat, cerita ulang (biografi), puisi dan resensi buku baik melalui lisan maupun tulisan. Dari beberapa Kompetensi Dasar tersebut, kesulitan utama yang dihadapi siswa adalah dalam meyusun teks eksposisi.

Berdasarkan hasil wawancara observasi awal dengan guru mata pelajaran Bahasa Indonesia SMA Negeri 3 Medan, yaitu dengan Bapak M. Sadri Koto S.Pd dan berdasarkan Program Pengalaman Lapangan Terpadu (PPLT), bahwa nilai hasil pembelajaran keterampilan menulis eksposisi masih rendah, rata-rata nilai yang diperoleh oleh siswa kelas X SMA Negeri 3 Medan adalah 6,7 yang berarti belum sesuai dengan yang diharapkan. Dalam proses pembelajaran bahasa Indonesia selama dua tahun terakhir, siswa SMA Negeri 3 Medan terutama siswa kelas X masih mengalami kendala.

Salah satu kendala tersebut antara lain, siswa masih kurang cermat dalam memahami konteks kalimat efektif dalam penyusunan jenis-jenis teks atau paragraf, khususnya paragraf eksposisi. Dari pemerolehan data hasil nilai rata-rata ulangan harian dan tugas-tugas harian selama PPLT, kompetensi dasar keterampilan menulis terutama keterampilan menulis eksposisi masih kurang memuaskan.Standar kelulusan atau criteria ketuntasan minimal (KKM) di SMA Negeri 3 Medan adalah 70 sedangkan nilai rata-rata yang diperoleh oleh siswa hanya mencapai 67.Artinya, belum memenuhi standar kelulusan atau kriteria ketuntasan minimal (KKM).

Ketidak tercapaian nilai KKM tersebut terjadi karena adanya beberapa faktor yang kurang sesuai dengan standar pendidikan.Selain faktor keterampilan menulis merupakan keterampilan paling sulit di antara keterampilan berbahasa lainnya, salah satu faktor utama dalam hal ini ialah penggunaan strategi pembelajaran yang kurang tepat. Strategi pembelajaran yang diterapkan sebelumnya masih tergolong pembelajaran konvensional karena proses pembelajaran hanya berupa penyampaian materi yang terkait dengan jenis teks yang dipelajari dan pemberian contoh teks yang bersumber dari buku pegangan siswa. Pembelajaran menulis teks eksposisi termasuk pembelajaran yang kurang diminati dan kurangnya motivasi terhadap pembelajaran tersebut.

Hal ini sejalan dengan penelitian sebelum yang dilakukan oleh Nisa Miftakhul Janah dengan judul “Hubungan Minat Baca Dan Penguasaan Kosakata Dengan Kemampuan 
Menulis Teks Eksposisi Pada Siswa Kelas X Sma Negeri Sekabupaten Bantul” bahwa siswa masih mengalami kesulitan pada saat meulis teks eksposisi. Kurangnya minat baca pada siswa akan mempengaruhi kosakata yang dimiliki oleh siswa. Kemudian penelitian yang lain dilakukan oleh Rizki Fitriyadi dengan judul “Pengaruh Penguasaan Kosakata Dan Tata Bahasa Indonesia Terhadap Kemampuan Menulis EksposisiSiswa Kelas X Sma Negeri Se Kota Yogyakarta.Hal ini juga yang menjadi bahan pertimbangan penulis untuk melakukan penelitian pada SMA Negeri 3 Medan.

Kalimat efektif merupakan kalimat yang dapat mengomunikasikan pikiran atauperasaan pembicara atau penulis kepada pendengar atau pembaca secara tepat dan jelas sehingga tidak terjadi keraguan dan kesalahan pengertian.Membicara kalimat efektif tidak lepas dari ciri-ciri yang terdapat didalamnya. Berikut ini ciri-ciri kalimat efektif menurut Alkhadiah (1999:116-117) dalam Dalman (2014:24) antara lain: kesepadanan dan kesatuan, kesejajaran bentuk, penekanan, kehematan dan kevariasian.

Teks eksposisi adalah tulisan tentang uraian atau argument terhadap suatu hal untuk mengusulkan sesuatu berdasarkan satu argumentasi yang didukung oleh fakta, pendapat para ahli, atau kejadian dengan struktur pernytaan pendapat (tesis), argumentasi, penegasan ulang pendapat.Menurut Isnatun (2013:69) teks ekposisi memiliki empat ciri-ciri sebagai berikut:

1. Berisi tentang pendapat, gagasan, atau keyakuna penulis terhadap suatu masalah bidang tertentu,

2. Uraian bersifat objektif, semata-mata hanya untuk menambah pengetahuan pembaca tanpa didasari maksud tertentu,

3. Diperjelas dengan fakta yang dilengkapi dengan angka, peta, grafik, statistic, gambar atau bagan sebagai ilustrasi,

4. Paragraph di akhiri dengan penegasan, bukan ajakan atau permintaan dukungan. (2013:69)

\section{METODE PENELITIAN}

Penelitian adalah suatu proses yaitu rangkaian kegiatan yang dilakukan secara terencana dan sistematis. Dalam suatu penelitian yang akan dilakukan, metode memang memiliki peranan yang penting, hal ini dikarenakan kegiatan yang dilakukan dalam penelitian bergantung pada metode yang digunakan.

Penelitian ini bertujuan untuk membuktikan apakah ada hubungan positif yang signifikan antara penguasaan kalimat efektif dengan kemampuan menulis teks eksposisi 
tahun pembelajaran 2016/2017. Hal ini sesuai dengan pendapat Arikunto (2010:313) yang menyatakan “ ..... penelitian korelasi bertujuan untuk menentukan ada tidaknya hubungan, apabila ada seberapa eratnya serta berarti atau tidaknya hubungan ini”. Oleh karena itu, penelitian ini menggunakan metode deskriptif korelasional untuk melihat hubungan antara variable $\mathrm{X}_{1}$ terhadap $\mathrm{Y}$.

Data yang diperoleh selanjutnya dianalisis secara statistik dengan langkah-langkah analisis yaitu data hasilpenguasaan kalimat efektifdan hasil dari kemampuan menulis teks eskposisi oleh siswadisusun dalam bentuk tabel, menentukan nilai rata-rata dan standar deviasi dari data hasilpenguasaan kalimat efektif, menghitung uji normalitas, uji homogenitas, danuji hipotesis. Setelah t diketahui maka nilai tersebut akan dikonsultasikan dengan tabel pada taraf signifikan 5\% dengan derajat kebebasan $(\mathrm{dk})=\mathrm{n}-1$ pada taraf nyata $\alpha$

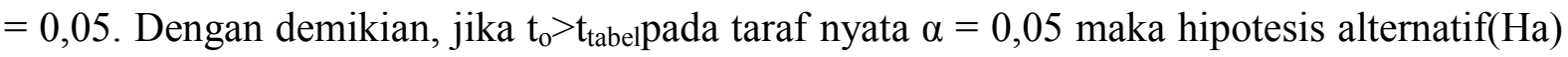
diterima.

\section{HASIL PENELITIAN DAN PEMBAHASAN}

\section{Hasil Penelitian}

1. Penguasaan Kalimat Efektif Siswa Kelas X SMA Negeri 3 Medan Tahun Ajaran 2016/2017

Penguasaan Kalimat Efektif Siswa Kelas X SMA Negeri 3 Medan Tahun Ajaran 2016/2017 memperoleh nilai hasil rata-rata sebesar 75.2. Apabila perhitungan ini dikonsultasikan pada ketentuan seperti disebutkan pada Bab III, yaitu “ Nilai 85-100 kategori sangat baik, nilai 70-84 kategori baik, nilai 55-69 cukup baik, nilai 40-54 kategori kurang baik, nilai 0-39 kategori sangat kurang baik. Dengan nilai rata-rata penguasaan kalimat efeftif sebesar 75.2 berada pada kategori baik.

\section{Kemampuan Menulis Teks Eksposisi Siswa Kelas X SMA Negeri 3 Medan Tahun}

\section{Ajaran 2016/2017}

Kemampuan Menulis Teks Eksposisi Siswa Kelas X SMA Negeri 3 Medan Tahun Ajaran 2016/2017 memperoleh nilai hasil rata-rata sebesar 77.74. Apabila perhitungan ini dikonsultasikan pada ketentuan seperti disebutkan pada Bab III, yaitu " Nilai 85-100 kategori sangat baik, nilai 70-84 kategori baik, nilai 55-69 cukup baik, nilai 40-54 kategori kurang baik, nilai 0-39 kategori sangat kurang baik. Dengan nilai rata-rata kemampuan menulis teks eksposisi sebesar 77.50 berada pada kategori baik. 


\section{Hubungan Penguasaan Kalimat Efektif Dengan Kemampuan Menulis Teks Eskposisi}

Berdasarkan uji analisis dan normalitas dari data penguasaan kalimat efektif dankemampuan menulis teks eksposisi yang diperoleh siswa merupakan data yang berdistribusi normal.Diperoleh harga $\mathrm{L}_{\text {hit }}=0,84$. Sedangkan dari tabel L untuk uji Liliefors dengan jumlah sampel (n) $=85$ dan taraf, nyata $\alpha=0,05$ maka nilai $\mathrm{L}_{\text {tab }}=0,93$. Karena $\mathrm{L}_{\text {hit }}<$ $\mathrm{L}_{\text {tab }}(0,76<0,93)$. Maka dapat disimpulkan bahwa data penguasaan kalimat efektif tersebut berdistribusi normal.

Diperkirakan bahwa hubungan penguasaan kalimat efektif dengan kemampuan menulis teks eksposisi oleh siswa pada sampel 85 orang kelinieran persamaan regresi $Y=62,32+$ $0,601 \mathrm{X}$ berarti pada taraf signifikan $\alpha=0,05$. Dapat disimpulkan bahwa hipotesis yang menyatakan bahwaÝ $=62,32+0,601 \mathrm{X}(85)$ merupakan regresi linier dan tidak perlu dicari model regresi nonlinier. Untuk uji keberartian regresi di peroleh nilai hitung $\mathrm{F}_{\text {hit }}=2,111$ sedangkan nilai $\mathrm{F}_{\text {tabel }}=1,450$ dengan $\mathrm{dk}=\mathrm{N}-1=84$. Karena nilai $\mathrm{F}_{\text {hitung }}>\mathrm{F}_{\text {tabel }}(2,111>1,450)$ maka dapat disimpulkan bahwa kelinieran persamaan regresi $Y^{\prime}=62,32+0,601 \mathrm{X}$ berarti pada taraf signifikan $\alpha=0,05$. Namun dalam korelasi rendah.

\section{Pembahasan Hasil Penelitian}

Berdasarkan hasil data yang diperoleh dari tabel penguasaan kalimat efektif diketahui bahwa jumlah sampel yang diteliti sebanyak 85 orang siswa yang diperoleh dari populasi sebesar 854 orang siswa kelas X SMA Negeri 3 Medan, jadi sampel yang digunakan sebesar $10 \%$ dari jumlah populasi. Pengumpulan data melalui tes penilaian penguasaan kalimat efektif sebanyak 25 butir soal dengan pilihan berganda a,b,c,d,dan e. Hasil tes yang diperoleh dari penguasaan kalimat efektif oleh siswa kelas X SMA Negeri 3 Medan yaitu 75,2 dengan kategori baik.

Pengumpulan data untuk kemampuan menulis teks eksposisi diperoleh dengan memberikan penugasan kepada siswa untuk menulis teks eksposisi, penilaian menulis teks ekspsisi menggunakan empat indikator yaitu isi karangan, penggunaan tatabahasa, hal yang diinformasikan pada teks eksposisi dan kesimpulan. Hasil tes yang diperoleh dari kemampuan menulis teks eksposisi oleh siswa kelas X SMA Negeri 3 Medan yaitu 77,74 dengan kategori baik.

Kemudian apabila kita lihat dari tabel distribusi frekuensi diketahui bahwa penguasaan kalimat efektif mayoritas siswa memiliki nilai dalam kategori baik, yaitu : 8 
orang siswa dalam kategori sangat baik $(9,41 \%), 63$ orang siswa dalam kategori baik $(74,11 \%), 14$ orang siswa dalam kategori cukup baik $(16,47 \%)$ sedang kategori kurang baik dan sangat kurang baik tidak ada.

Kemampuan menulis teks eksposisi didominasi oleh siswa yang memiliki nilai dalam kategori sangat baik, yakni 11 orang siswa (12,94\%), siswa yang memiliki nilai dalam kategori baik sebanyak 70 orang siswa $(82,35 \%)$ dan siswa yang memiliki nilai dalam kategori cukup baik sebanyak 4 orang siswa (4.70\%). Tidak ada satupun siswa yang memiliki nilai dalam kategori kurang baik dan sangat kurang baik.Hubungan penguasaan kalimat efektif dengan kemampuan menulis teks eksposisi oleh siswa pada sampel 85 orang kelinieran persamaan regresi $Y=62,32+0,601 \mathrm{X}$ berarti pada taraf signifikan $\alpha=0,05$.

Untuk uji keberartian regresi di peroleh nilai hitung $\mathrm{F}_{\text {hit }}=2,111$ sedangkan nilai $\mathrm{F}_{\text {tabel }}=$ 1,450 dengan $\mathrm{dk}=\mathrm{N}-1=84$. Karena nilai $\mathrm{F}_{\text {hitung }}>\mathrm{F}_{\text {tabel }}(2,111>1,450)$ maka dapat disimpulkan bahwa kelinieran persamaan regresi $Y=62,32+0,601 \mathrm{X}$ berarti pada taraf signifikan $\alpha=0,05$ dengan korelasi yang tergolong rendah.

Pengujian homogenitas dilakukan dengan menggunakan Uji Barlett. Tabel yang digunakan untuk mencari nilai $\chi_{\text {tabel }}^{2}$ adalah tabel $\chi^{2}$ dengan $\mathrm{dk}=\mathrm{k}-1=2-1=1$. Nilai $\chi_{\text {tabel }}^{2}$ nya adalah 3,841 dan ternyata $\chi_{\text {hitung }}^{2}<\chi_{\text {tabel }}^{2}$ atau $10,56<3,841$. Karena nilai $\chi_{\text {hitung }}^{2}$ $\chi_{\text {tabel }}^{2}$ maka dapat disimpulkan data tersebut homogen.

Dari hasil uji hipotesis yang sudah dijelaskan diatas maka terdapat hubungan yang signifikan antara penguasaan kalimat efektif dengan kemampuan menulis teks eksposisi yaitu sebesar $8,35 \%$

Keterkaitan penguasaan kalimat efektif dengan kemampuan menulis teks eksposisi ke dalam sebuah paragraf sebuah tulisan sangatlah ditentukan bagaimana siswa tersebut menggunakan kata yang tepat sehingga tujuan atau makna yang terkandung dalam kalimat dapat disampaikan dengan baik.

Penguasaan kalimat efektif dalam menulis teks eksposisi sangat membantu pembaca dan penulis dalam satu pemikiran dengan apa yang dibaca dan ditulis. kalimat efektif adalah kalimat yang dapat mengkomunikasikan pikian atau perasaan pembicara atau penulis secara tepat dan jelas sehingga tidak terjadi keraguan dan kesalahan pengertian. Menurut Tarigan (2008:11) “menulis merupakan kegiatan menuangkan atau melukiskan lambang-lambang grafik yang menggambarkan bahasa yang dipahami seseorang agar orang lain dapat membaca lambang-lambang grafik tersebut" 


\section{PENUTUP}

Berdasarkan keseluruh anuraian hasil penelitian, dapat ditarik beberapa kesimpulan sebagai berikut, yaitu penguasaan kalimat efektif oleh siswa kelas X SMA Negeri 3 Medan tahun pembelajaran 2016/2017 berada dalam kategori baik denganrata-rata penguasaan kalimat efektif $(X)=75.2$. Kemampuan menulis teks eksposisi oleh siswa kelas X SMA Negeri 3 Medan tahun pembelajaran 2016/2017 berada dalam kategori baik dengan nilai ratarata kamampuan menulis teks eskposisi sebesar 77.50 berada pada kategori baik.Terdapat hubungan yang positif dan signifikan antara penguasaan kalmia tefektif dengan kemampuan menulis teks eskposisi oleh siswa kelas X SMA Negeri 3 Medan tahun pembelajaran $2015 / 2016$ sebesar $8,35 \%$.

\section{DAFTAR PUSTAKA}

Tarigan, H. G. 2008. Menulis Sebagai Suatu Keterampilan berbahasa.Bandung: Angkasa2 Akhadiah, dkk.1999. Pembinaan Kemampuan Menulis Bahasa Indonesia. Jakarta: Erlangga Dalman, H. 2014. Keterampilan Menulis. Jakarta: Raja Grafindo Isanatun, Siti dan Umi Farida.2013. Mahir Berbahasa Indonesia.Bogor: Yudhistira Arikunto, Suharsimi. 2010. Prosedur Penelitian Suatu Pendekatan Praktik. Jakarta: Rineka Cipta 